\title{
Gospodarka odpadami Instalacje i urządzenia do przetwarzania odpadów
}

\section{Anna Wieczorek, Maciej Siekierski}

\section{STRESZCZENIE}

Gospodarka odpadami, to skomplikowany proces, który w największym skrócie można scharakteryzować jako wytwarzanie odpadów oraz gospodarowanie odpadami. Kluczowe znaczenie w gospodarowaniu odpadami ma ich przetwarzanie. Do przetwarzania odpadów - odzysku i unieszkodliwiania - niezbędne są odpowiednie instalacje oraz urządzenia, których przytłaczająca większość to inwestycje celu publicznego, w rozumieniu ustawy o planowaniu i zagospodarowaniu przestrzennym oraz przedsięwzięcia mogące zawsze znacząco oddziaływać na środowisko, w rozumieniu rozporządzenia w sprawie przedsięwzięć mogących znacząco oddziaływać na środowisko. Powyższe instalacje i urządzenia sa traktowane jako obiekty budowlane w rozumieniu ustawy Prawo budowlane albo sa umieszczane $\mathrm{w}$ takich obiektach. Artykuł jest drugim z serii artykułów poświęconych gospodarce odpadami. Dotyczy zasad realizacji obiektów budowlanych, w których następuje przetwarzanie odpadów i związanych z tym problemów. Autorzy uważają, że podstawowymi przyczynami kłopotów są zbyt skomplikowane procedury ustalania lokalizacji i uzyskiwania decyzji o pozwoleniu na budowę oraz negatywne emocje społeczne - ludzie nie chcą mieć w swoim sąsiedztwie takich obiektów.

Nie są przedmiotem niniejszego artykułu szczegółowe rozważania dotyczące: uproszczenia procedur ustalania lokalizacji powyższych obiektów budowlanych, technologii bezpiecznych dla środowiska, liczby instalacji niezbędnych do prawidłowego gospodarowania odpadami w Polsce, zachęt ekonomicznych. To tematy zbyt obszerne na jeden artykuł. Wymagają szeregu odrębnych badań i publikacji.

Autorzy sygnalizuja jedynie: które akty prawa należy przede wszystkim zmienić, aby uprościć procedury oraz sposoby na ostudzenie negatywnych emocji: zachęty ekonomiczne dla właścicieli nieruchomości, położonych w szeroko rozumianym sąsiedztwie powyższych obiektów.

Słowa kluczowe: przedsięwzięcia mogące zawsze znacząco oddziaływać na środowisko, odpady, gospodarka odpadami, gospodarowanie odpadami, przetwarzanie odpadów, termiczne przekształcanie odpadów

\section{Odpady}

Podstawowym aktem prawa, dotyczącym odpadów oraz gospodarki odpadami, jest ustawa o odpadach (uod), która w zakresie swojej regulacji wdraża dyrektywy Unii Europejskiej.

Pod pojęciem odpady rozumie się „każdą substancję lub przedmiot, których posiadacz pozbywa się, zamierza się pozbyć lub do których pozbycia się jest obowiązany" [art. 3 ust. 1 pkt 6 uod].

Można wyróżnić kilka sposobów katalogowania odpadów. Ustawa o odpadach definiuje następujące pojęcia: 
- bioodpady [art. 3 ust. 1 pkt 1 uod],

- odpady komunalne [art. 3 ust. 1 pkt 7 uod],

- odpady medyczne [art. 3 ust. 1 pkt 8 uod],

- odpady obojętne [art. 3 ust. 1 pkt 9 uod],

- odpady ulegające biodegradacji [art. 3 ust. 1 pkt 10 uod],

- odpady weterynaryjne [art. 3 ust. 1 pkt 11 uod],

- odpady zielone [art. 3 ust. 1 pkt 12 uod],

- $\quad$ odpady z wypadków [art. 3 ust. 1 pkt 13 uod],

- oleje odpadowe [art. 3 ust. 1 pkt 16 uod],

- $\quad$ PCB (np. polichlorowane bifenyle, polichlorowane trifenyle) [art. 3 ust. 1 pkt 17 uod]. Przepisów ustawy o odpadach nie stosuje się do substancji takich, jak np.:

- gazy i pyły wprowadzane do atmosfery oraz dwutlenek węgla składowany pod ziemia,

- ziemia i skały przemieszczane przy robotach budowlanych i wydobywaniu kopalin,

- odpady promieniotwórcze,

- wycofane z użytku materiały wybuchowe,

- biomasy: odchody zwierzat, słoma, substancje z produkcji rolniczej lub leśnej,

- osady związane z gospodarowaniem wodami oraz ścieki,

- produkty uboczne pochodzenia zwierzecego oraz zwłoki zwierząt [art. 2 uod].

Powyższe substancje w powszechnym odczuciu są uznawane za odpady. Rozporządzenie Ministra Klimatu, w sprawie katalogu odpadów, dzieli odpady na 20 grup, w zależności od źródła ich powstawania, a w ramach grup wyróżnia podgrupy i rodzaje ze wskazaniem odpadów niebezpiecznych [§ 1 i $\S 2]$.

\section{Gospodarka odpadami}

Gospodarka odpadami, to skomplikowany proces (ryc. 1), który w największym skrócie można scharakteryzować jako:

- wytwarzanie odpadów;

- gospodarowanie odpadami [art. 3 ust. 1 pkt 3 uod].

„Każda gospodarcza działalność człowieka łączy się obecnie w sposób nierozerwalny z produkowaniem odpadów. Rozwiązaniem idealnym, niemożliwym do zastosowania na większą skalę, ani teraz, ani w najbliższej przyszłości, jest stosowanie technologii bezodpadowych." [Nowicki 1993, s. 129]. 


\section{GOSPODARKA ODPADAMI}

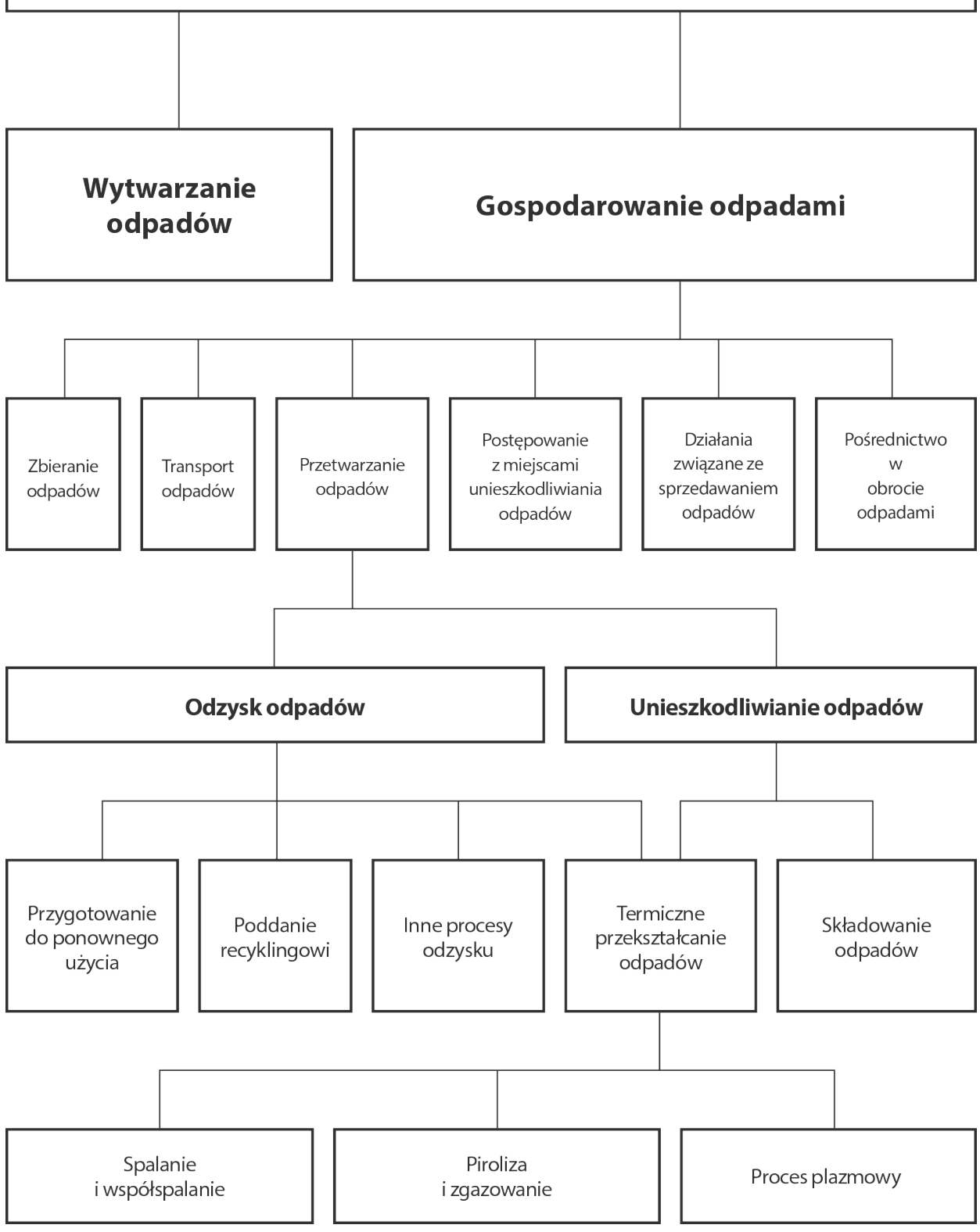

Ryc. 1. Gospodarka odpadami

Źródło: opracowanie własne 
Skoro działalność człowieka łączy się z wytwarzaniem odpadów, a w najbliższej przyszłości nie ma szans na stosowanie technologii całkowicie bezodpadowych, to należy skupić się na rozsądnym gospodarowaniu odpadami. Gospodarowanie odpadami to:

- zbieranie odpadów (w tym nadzór nad tym działaniem),

- transport odpadów (w tym nadzór nad tym działaniem),

- przetwarzanie odpadów (w tym nadzór nad tym działaniem),

- postępowanie z miejscami unieszkodliwiania odpadów,

- działania związane ze sprzedawaniem odpadów,

- $\quad$ pośrednictwo w obrocie odpadami [art. 3 ust. 1 pkt 2 uod].

Rozporządzenie w sprawie szczegółowego sposobu selektywnego zbierania wybranych frakcji odpadów nakazuje selektywną ich zbiórkę, w podziale na papier, szkło, metale, tworzywa sztuczne oraz odpady ulegające biodegradacji, ze szczególnym uwzględnieniem bioodpadów [§ 3]. Rachunek ekonomiczny oraz zdrowy rozsadek nakazuje, aby nie transportować odpadów na duże odległości. Kluczowe znaczenie ma przetwarzanie odpadów - „procesy odzysku lub unieszkodliwiania, w tym przygotowanie poprzedzające odzysk lub unieszkodliwianie" [art. 3 ust. 1 pkt 21 uod].

Odzysk, to „,jakikolwiek proces, którego głównym wynikiem jest to, aby odpady służyły użytecznemu zastosowaniu przez zastapienie innych materiałów, które w przeciwnym przypadku zostałyby użyte do spełnienia danej funkcji, lub w wyniku którego odpady sa przygotowywane do spełnienia takiej funkcji w danym zakładzie lub ogólnie w gospodarce" [art. 3 ust. 1 pkt 14 uod]. Odzysk polega na przygotowaniu odpadów do ponownego użycia lub poddaniu recyklingowi [art. 18 ust. 2 i ust 3 uod]. Przygotowanie do ponownego użycia, to „odzysk polegający na sprawdzeniu, czyszczeniu lub naprawie, w ramach którego produkty lub części produktów, które wcześniej stały się odpadami, są przygotowywane do tego, aby mogły być ponownie wykorzystywane bez jakichkolwiek innych czynności wstępnego przetwarzania" [art. 3 ust. 1 pkt 22 uod].

Recykling, to „odzysk, w ramach którego odpady sa ponownie przetwarzane na produkty, materiały lub substancje wykorzystywane w pierwotnym celu lub innych celach; obejmuje to ponowne przetwarzanie materiału organicznego (recykling organiczny), ale nie obejmuje odzysku energii i ponownego przetwarzania na materiały, które maja być wykorzystane jako paliwa lub do celów wypełniania wyrobisk" [art. 3 ust. 1 pkt 23 uod].

Recykling organiczny polega na „obróbce tlenowej, w tym kompostowaniu, lub obróbce beztlenowej odpadów, które ulegają rozkładowi biologicznemu w kontrolowanych warunkach przy wykorzystaniu mikroorganizmów, w wyniku której powstaje materia organiczna lub metan; składowanie na składowisku odpadów nie jest traktowane jako recykling organiczny" [art. 18 ust. 4 uod]. Załącznik nr 1 do ustawy o odpadach zawiera wykaz procesów odzysku. Jak ujęto w ustawie - jest to wykaz niewyczerpujacy [art. 3 ust. 2 uod], co oznacza, że można, a nawet trzeba go uzupełniać, wykorzystując badania naukowe i wiedzę czerpaną $\mathrm{z}$ praktyki.

Unieszkodliwianie odpadów, to „proces niebędący odzyskiem, nawet jeżeli wtórnym skutkiem takiego procesu jest odzysk substancji lub energii" [art. 3 ust. 1 pkt 30 uod]. Uniesz- 
kodliwianiu poddaje się odpady, których poddanie odzyskowi nie było możliwe z przyczyn technologicznych, ekologicznych lub ekonomicznych [art. 18 ust. 3 i ust. 5 uod], a także te, z których uprzednio wysegregowano to, co nadaje się do odzysku [art. 18 ust. 7 uod].

Składowaniu powinny podlegać wyłącznie odpady, których unieszkodliwienie w inny sposób było niemożliwe [art. 18 ust. 3 i ust. 6 uod]. Załącznik nr 2 do ustawy o odpadach zawiera wykaz procesów unieszkodliwiania. Podobnie jak w przypadku wykazu procesów odzysku jest to wykaz niewyczerpujący [art. 3 ust. 3 uod], czyli można go uzupełniać.

Proces, który może polegać zarówno na unieszkodliwianiu odpadów, jak i ich odzysku, to termiczne przekształcanie odpadów, czyli spalanie odpadów przez ich utlenianie, inne procesy termicznego przetwarzania, np.: piroliza i zgazowanie oraz proces plazmowy [art. 3 ust. 1 pkt 29 uod].

Ustawa o odpadach wprowadza hierarchię sposobów postępowania z odpadami:

- zapobieganie ich powstawaniu,

- przygotowywanie do ponownego użycia,

- recykling albo inne procesy odzysku,

- unieszkodliwianie [art. 17 uod].

Z powyższego wynika, że przede wszystkim trzeba zapobiegać powstawaniu odpadów. Jeśli już powstana, to należy skupić się na ich przetwarzaniu w sposób najmniej szkodliwy dla środowiska. Odpady powinno się przygotować do ponownego użycia, poddać recyklingowi lub innemu procesowi odzysku. Jeśli odzysk nie jest możliwy to unieszkodliwić.

\section{Plany gospodarki odpadami}

Podstawowymi dokumentami określającymi zasady gospodarki odpadami sa plany gospodarki odpadami, które wykonuje się dla całego krajowym i poszczególnych województw [art. 34 ust. 3 uod]. Są to - krajowy plan gospodarki odpadami oraz wojewódzki plan gospodarki, do którego załącznikiem jest plan inwestycyjny [art. 35a ust. 4].

Plany gospodarki odpadami są sporządzane dla osiagnięcia „celów założonych w polityce ochrony środowiska, oddzielenia tendencji wzrostu ilości wytwarzanych odpadów i ich wpływu na środowisko od tendencji wzrostu gospodarczego kraju, wdrażania hierarchii sposobów postępowania z odpadami oraz zasady samowystarczalności i bliskości, a także utworzenia i utrzymania w kraju zintegrowanej i wystarczającej sieci instalacji gospodarowania odpadami, spełniających wymagania ochrony środowiska" [art. 34 ust. 1].

Podstawowe informacje, jakie zawieraja plany gospodarki odpadami, to:

- cele i terminy ich osiagnięcia, wynikające z analizy aktualnego stanu tej gospodarki,

- kierunki działań, w tym „określenie kryteriów lokalizacji obiektów przeznaczonych do gospodarowania odpadami oraz mocy przerobowych przyszłych instalacji do przetwarzania odpadów",

- harmonogram realizacji przyjętych działań, w tym określenie sposobu finansowania [art. 35 ust. 1, pkt 1 do 5 uod]. 
Projekt krajowego planu gospodarki odpadami opracowuje minister właściwy do spraw klimatu, w porozumieniu z ministrem właściwym do spraw gospodarki wodnej, a uchwala Rada Ministrów [art. 36 ust. 1 uod].

Projekt wojewódzkiego planu gospodarki sporządza zarząd województwa [art. 36 ust. 2 uod], w tym:

- przekazuje go do zaopiniowania organom wykonawczym gmin z obszaru województwa, dyrektorowi regionalnego zarządu gospodarki wodnej Państwowego Gospodarstwa Wodnego Wody Polskie w zakresie ochrony wód [art. 36 ust. 4 uod] oraz ministrowi właściwemu do spraw klimatu [art. 36 ust. 5 uod],

- uzgadnia projekt planu inwestycyjnego z ministrem właściwym do spraw klimatu [art. 35a ust. 3 i art. 36 ust. 5 uod].

Wojewódzki plan gospodarki odpadami uchwala sejmik województwa [art. 36 ust. 2 uod]. Plan inwestycyjny wskazuje planowane inwestycje, ich koszty i źródła finansowania oraz harmonogram realizacji [art. 35a ust. 2 uod]. „Warunkiem dopuszczalności finansowania budowy, rozbudowy lub modernizacji instalacji przeznaczonych do przetwarzania odpadów komunalnych, w tym odpadów budowlanych i rozbiórkowych, ze środków Unii Europejskiej lub funduszy ochrony środowiska i gospodarki wodnej jest ich ujęcie w planie inwestycyjnym (...) warunek ten nie dotyczy instalacji do recyklingu odpadów." [art. 35 ust. 9 uod].

Obecnie obowiązuje Krajowy plan gospodarki odpadami 2022, przyjęty przez Radę Ministrów uchwałą nr 88 z dnia 1 lipca 2016 r. Na terenie województwa mazowieckiego obowiązuje Plan gospodarki odpadami dla województwa mazowieckiego 2024 przyjęty uchwałą nr 3/19 Sejmiku Województwa Mazowieckiego z dnia 22 stycznia 2019 r.

Nie jest przedmiotem artykułu szczegółowe badanie ustaleń Krajowego planu gospodarki odpadami 2022, jak i planów gospodarki odpadami poszczególnych województw, ale nawet pobieżna analiza nie pozostawia watpliwości, że jest zbyt mało instalacji oraz urządzeń do przetwarzania odpadów, a czesść tych instalacji wymaga rozbudowy i zmiany technologii.

\section{Instalacje oraz urządzenia do przetwarzania odpadów}

Instalacje oraz urządzenia do przetwarzania odpadów - odzysku i unieszkodliwiania, $\mathrm{w}$ tym termicznego przekształcania odpadów - w przytłaczającej większość są inwestycjami celu publicznego, w rozumieniu ustawy o planowaniu i zagospodarowaniu przestrzennym (upzp), przedsięwzięciami mogacymi zawsze znacząco oddziaływać na środowisko, w rozumieniu rozporządzenia w sprawie przedsięwzięć mogących znacząco oddziaływać na środowisko (rpzoś), wydanego na podstawie ustawy o udostępnianiu informacji o środowisku i jego ochronie, udziale społeczeństwa w ochronie środowiska oraz o ocenach oddziaływania na środowisko (uiś). Powyższe instalacje i urządzenia są traktowane jako obiekty budowlane w rozumieniu ustawy Prawo budowlane $(\mathrm{uPb})$ albo są umieszczane w takich obiektach. Ich realizacja wymaga uzyskania decyzji o pozwoleniu na budowę. 
Pod pojęciem obiekt budowlany należy rozumieć „budynek, budowlę bądź obiekt małej architektury, wraz z instalacjami zapewniającymi możliwość użytkowania obiektu zgodnie z jego przeznaczeniem, wzniesiony z użyciem wyrobów budowlanych" [art. 3 pkt $1 \mathrm{uPb}$ ]. Budynek, to „obiekt budowlany, który jest trwale związany z gruntem, wydzielony z przestrzeni za pomoca przegród budowlanych oraz posiada fundamenty i dach" [art. 3 pkt 2 uPb]. Budowle, to obiekty budowlane niebędące budynkami lub obiektami małej architektury, takie jak np.: „,wolno stojace instalacje przemysłowe lub urządzenia techniczne, oczyszczalnie ścieków, składowiska odpadów, (...) części budowlane urządzeń technicznych (kotłów, pieców przemysłowych, elektrowni jądrowych, elektrowni wiatrowych i innych urządzeń) oraz fundamenty pod maszyny i urządzenia, jako odrębne pod względem technicznym części przedmiotów składających się na całość użytkowa" [art. 3 pkt 3 uPb].

Obiekty budowlane służące do przetwarzania odpadów są inwestycjami celu publicznego [art. 2 pkt 5 upzp], ponieważ są celami publicznymi w rozumieniu ustawy o gospodarce nieruchomościami (ugn). Celami publicznymi są m.in. „budowa i utrzymywanie publicznych urządzeń służących do (...) odzysku i unieszkodliwiania odpadów, w tym ich składowania" [art. 6 pkt 3 ugn].

Pod pojęciem przedsięwzięcie rozumie się „zamierzenie budowlane lub inną ingerencję w środowisko polegającą na przekształceniu lub zmianie sposobu wykorzystania terenu, w tym również na wydobywaniu kopalin; przedsięwzięcia powiązane technologicznie kwalifikuje się jako jedno przedsięwzięcie, także jeżeli są one realizowane przez różne podmioty" [art. 3 ust. 1 pkt 13 uiś].

Rozporządzenie, które dotyczy przedsięwzięć mogących zawsze znacząco oddziaływać na środowisko zawiera wykaz tych przedsięwzięć. Są to:

1. wymienione $\mathrm{w}$ ustawie o odpadach instalacje do przetwarzania:

- "odpadów niebezpiecznych, w tym składowiska odpadów niebezpiecznych oraz miejsca retencji powierzchniowej odpadów niebezpiecznych" [§ 2 ust. 1 pkt 41 rpzoś],

- "odpadów innych niż niebezpieczne przy zastosowaniu procesów termicznego przekształcania odpadów, krakingu odpadów, fizykochemicznej obróbki odpadów (...) mające wydajność nie mniejszą niż 100 t dziennie, z wyłączeniem instalacji do odzysku odpadów będących biomasa" [§ 2 ust. 1 pkt 46 rpzoś],

- odpadów innych niż wymienione powyżej, w tym składowiska odpadów inne niż wymienione powyżej, ",mogące przyjmować odpady w ilości nie mniejszej niż $10 \mathrm{t}$ na dobę lub o całkowitej pojemności nie mniejszej niż 25000 t, z wyłączeniem instalacji do wytwarzania biogazu rolniczego" [§ 2 ust. 1 pkt 47 rpzoś];

2. wymienione w ustawie o odpadach wydobywczych:

- „obiekty unieszkodliwiania odpadów wydobywczych kategorii A” [§ 2 ust. 1 pkt 48 rpzoś],

- „obiekty unieszkodliwiania odpadów wydobywczych (...) mogące przyjmować odpady w ilości nie mniejszej niż 10 t na dobę lub o całkowitej pojemności nie mniejszej niż 25000 t” [§ 2 ust. 1 pkt 49 rpzoś]; 
3. wymienione w ustawie o recyklingu pojazdów wycofanych z eksploatacji:

- $\quad$ stacje demontażu [§ 2 ust. 1 pkt 42 rpzoś],

- miejsca przetwarzania pojazdów inne niż wymienione powyżej stacje demontażu oraz „miejsca przetwarzania statków wycofanych z eksploatacji” [§ 2 ust. 1 pkt 43 rpzoś];

4. wymienione $\mathrm{w}$ ustawie o zużytym sprzęcie elektrycznym i elektronicznym zakłady przetwarzania „w których następuje demontaż obejmujący usunięcie ze zużytego sprzętu niebezpiecznych: substancji, mieszanin i części składowych” [§ 2 ust. 1 pkt 45 lit „a" rpzoś];

5. wymienione w ustawie o bateriach i akumulatorach zakłady przetwarzania „zużytych baterii lub zużytych akumulatorów (...) prowadzące przetwarzanie i recykling zużytych baterii i akumulatorów stanowiących odpady niebezpieczne” [§ 2 ust. 1 pkt 45 lit „b" rpzoś]. Rozpoczęcie budowy tego typu obiektów lub ich rozbudowa [art. 3 pkt 6 uPb] muszą być poprzedzone decyzja o pozwoleniu na budowę. Przed wydaniem decyzji o pozwoleniu na budowę organ administracji architektoniczno-budowlanej sprawdza m.in. zgodność projektu budowlanego z ustaleniami miejscowego planu zagospodarowania przestrzennego albo decyzji o warunkach zabudowy i zagospodarowania terenu ( $w$ przypadku braku takiego planu) oraz z wymaganiami ochrony środowiska określonymi w decyzji o środowiskowych uwarunkowaniach [art. 35 ust. 1 pkt 1 uPb]. Sumując, lokalizacja każdego obiektu budowlanego, którego budowa wymaga uzyskania pozwolenia na budowę musi być zgodna z przeznaczeniem oraz sposobem zagospodarowania i warunkami zabudowy terenu ustalonymi $\mathrm{w}$ miejscowym planie zagospodarowania przestrzennego [art. 4 ust. 1 upzp] albo w drodze decyzji o warunkach zabudowy i zagospodarowania terenu [art. 4 ust. 2 upzp].

Pod pojęciem: decyzja o warunkach zabudowy i zagospodarowania terenu rozumie się:

- decyzję o lokalizacji inwestycji celu publicznego, która, jak sama nazwa wskazuje, dotyczy inwestycji celu publicznego,

- $\quad$ decyzję o warunkach zabudowy, która dotyczy innych inwestycji [art. 4 ust. 2 upzp].

Ponadto budowa obiektów budowlanych będących przedsięwzięciami mogącymi zawsze znacząco oddziaływać na środowisko wymaga wydania decyzji o środowiskowych uwarunkowaniach, o której mowa w ustawie o udostępnianiu informacji o środowisku i jego ochronie, udziale społeczeństwa w ochronie środowiska oraz o ocenach oddziaływania na środowisko.

Wykonanie każdego projektu miejscowego planu zagospodarowania przestrzennego i jego uchwalenie potrafi trwać latami. Sporządzenie planu miejscowego, wyznaczającego ramy do realizacji przedsięwzięć mogących zawsze znacząco oddziaływać na środowisko, prócz spełnienia procedur wynikających z ustawy o planowaniu i zagospodarowaniu przestrzennym, wymaga przeprowadzenia strategicznej oceny oddziaływania na środowisko [art. 46 ust. 1 pkt 1 uiś], a tym samym sporządzenia prognozy oddziaływania na środowisko [art. 51 ust. 1 uiś]. Prognoza oddziaływania na środowisko określa stan środowiska oraz problemy jego ochrony przy realizacji powyższych przedsięwzięć oraz wskazuje rozwiązania alternatywne [art. 51 ust. 2 uiś]. Projekt planu miejscowego, żeby mógł być uchwalony przez radę gminy i stać się aktem prawa miejscowego:

- wymaga uzyskania szeregu uzgodnień, 
- jest wykładany do publicznego wglądu wraz z prognozą oddziaływania na środowisko podlega ocenie opinii publicznej, zwłaszcza lokalnej społeczności.

Próba ustalenia lokalizacji obiektu służącego do przetwarzania odpadów nie zawsze kończy się powodzeniem. Projekt planu może nie uzyskać niezbędnych uzgodnień albo zostanie oprotestowany przez mieszkańców, a radni go nie uchwalą w obawie przed wyborcami.

Uzyskanie decyzji o lokalizacji inwestycji celu publicznego jest również czasochłonne. Tym bardziej uzyskanie takiej decyzji dla przedsięwzięć mogących zawsze znacząco oddziaływać na środowisko, ponieważ prócz spełnienia procedur wynikających z ustawy o planowaniu i zagospodarowaniu przestrzennym, wymaga przeprowadzenia oceny oddziaływania na środowisko [art. 59 ust. 1 pkt 1 uiś], zakończonej wydaniem decyzji o środowiskowych uwarunkowaniach [art. 71 ust. 1 pkt 1 i art. 72 ust. 1 pkt 3 uiś]. Projekt decyzji może nie uzyskać niezbędnych uzgodnień albo zostanie oprotestowany i zaskarżony przez mieszkańców, którzy wygrają sprawę w sądzie.

Decyzja o pozwoleniu na budowę dla powyższych przedsięwzięć jest wydawana na podstawie miejscowego planu zagospodarowania przestrzennego albo decyzji o ustaleniu lokalizacji inwestycji celu publicznego. Jej wydanie, prócz spełnienia procedur wynikających z ustawy Prawo budowlane, wymaga ponownego przeprowadzenia oceny oddziaływania na środowisko [art. 59 ust. 1 pkt 1 uiś], a tym samym wydania kolejnej decyzji o środowiskowych uwarunkowaniach [art. 71 ust. 1 pkt 1 i art. 72 ust. 1 pkt 1 uiś]. Projekt decyzji może nie uzyskać niezbędnych uzgodnień albo zostać zaskarżony.

Jak wynika z powyższego, uzyskiwanie decyzji o pozwoleniu na budowę dla przedsięwzięć mogących zawsze znacząco oddziaływać na środowisko, w szczególności związanych z przetwarzaniem odpadów, jest czasochłonne i obarczone ryzykiem, że takiej decyzji się nie uzyska. Podstawowe powody takiego stanu rzeczy, to zbyt skomplikowane procedury, a także negatywne emocje społeczne, ponieważ mieszkańcy nie chcą mieć w swoim sąsiedztwie takich obiektów.

Uproszczenie procedur należy zacząć od zmian:

- ustawy o planowaniu i zagospodarowaniu przestrzennym, w szczególności korekty zakresu stanowienia i zasad sporządzania miejscowych planów zagospodarowania przestrzennego,

- ustawy o udostępnianiu informacji o środowisku i jego ochronie, udziale społeczeństwa w ochronie środowiska oraz o ocenach oddziaływania na środowisko, na podstawie której - dla tej samej instalacji do przetwarzania odpadów - przeprowadza się wielokrotnie podobne postępowanie sprawdzające środowiskowe uwarunkowania.

Szczegółowe rozważania dotyczące uproszczenia procedur to temat na szereg publikacji, a niniejszy artykuł ogranicza się jedynie do ich zasygnalizowania. Sumując, lokalizacja instalacji do przetwarzania odpadów (np. spalarni) wymaga:

1. określenia kryteriów lokalizacji w planie gospodarki odpadami, a dla tego typu planów: jest przeprowadzana strategiczna ocena oddziaływania na środowisko [art. 35 ust. 2 uod w związku z w art. 55 ust. 3 uiś] albo - w przypadku odstapienia od jej przeprowadzenia wymaga się uzasadnienia [art. 35 ust. 2 uod w związku z w art. 42 pkt 2 uiś]; 
2. ustalenia lokalizacji: $\mathrm{w}$ miejscowym planie zagospodarowania przestrzennego, dla którego jest przeprowadzana strategiczna ocena oddziaływania albo - w decyzji o lokalizacji inwestycji celu publicznego, dla której jest przeprowadzana ocena oddziaływania na środowisko, zakończona wydaniem decyzji o środowiskowych uwarunkowaniach;

3. uzyskania decyzji o pozwoleniu na budowę, dla której jest ponownie przeprowadzana ocena oddziaływania na środowisko, zakończona wydaniem decyzji o środowiskowych uwarunkowaniach.

Wielokrotne sprawdzanie uwarunkowań środowiskowych lokalizacji instalacji do przetwarzania odpadów wydłuża czas uzyskania pozwolenia na budowę, a jednocześnie nie wystarcza, aby zminimalizować negatywne emocje społeczne. Lokalizacje takich inwestycji sa oprotestowywane przez mieszkańców terenów sąsiednich.

Nie pomagaja również ustalenia ustawy o odpadach, które stanowią w sposób jednoznaczny, że instalacje i urządzenia do przetwarzania odpadów można eksploatować tylko, gdy:

- „spełniają wymagania ochrony środowiska, w tym nie powoduja przekroczenia standardów emisyjnych, o których mowa w przepisach o ochronie środowiska" [art.29 ust. 2 pkt 1 uod],

- "pozostałości powstające w wyniku działalności związanej z przetwarzaniem odpadów będa przetwarzane z zachowaniem wymagań określonych w ustawie" [art.29 ust. 2 pkt 2 uod].

Protestom trudno się dziwić, bo w społecznej pamięci funkcjonuje pochodzące jeszcze z czasów PRL głęboko zakorzenione przekonanie, że nawet najczystsza w teorii instalacja przemysłowa może się okazać finalnie skutecznym trucicielem wód i powietrza. Starsi mieszkańcy takich części Warszawy jak Tarchomin, a nawet Bielany i Żolibórz do tej pory pamiętają zapachy jakie towarzyszyły biotechnologicznym, wykorzystującym specyficzne gatunki grzybów pleśniowych, procesom produkcji antybiotyków w zakładach Polfa-Tarchomin [gazeta.pl 2021]. Mieszkańcy okolic warszawskiej Elektrociepłowni Siekierki wspominają opady czarnego śniegu związane z powtarzającymi się awariami tamtejszych elektrofiltrów [Mikołajczyk 2020]. Wspomnienia te, wzmacniane często zupełnie nie merytoryczną krytyką ze strony organizacji de nomine jedynie pro-środowiskowych, prowadzą do silnego oporu społeczności lokalnych wobec wszelkich przedsięwzięć mogących zawsze znacząco oddziaływać na środowisko. Skoro przy produkcji leków występowały skutki uboczne, to, co dopiero przy przetwarzaniu odpadów. Zazwyczaj w takich sytuacjach powstaje nieliczna, ale bardzo aktywna grupa zdecydowanych przeciwników inwestycji, których silne zaangażowanie prowadzi do uniemożliwienia nie tylko realizacji inwestycji, ale nawet rzeczowej dyskusji na jej temat.

Należy zadać pytanie, co trzeba zrobić, aby budowa instalacji i urządzeń do przetwarzania odpadów nie wywoływała negatywnych emocji społecznych. Wydaje się, że można próbować uzyskać to poprzez wskazywanie obiektów, które są rzeczywiście bezpieczne dla środowiska (dobre praktyki) albo zachęty ekonomiczne dla właścicieli nieruchomości, położonych w szeroko rozumianym sąsiedztwie powyższych obiektów. 
Biorąc pod uwagę, to, co napisano powyżej, wybierając przykłady dobrych praktyk, trzeba się liczyć z tym, że oponenci nie uwierza, iż wskazane obiekty są rzeczywiście bezpieczne, posadzą o lobbowanie za danym rozwiązaniem, z przyczyn - eufemistycznie mówiąc - pozamerytorycznych.

Wydaje się, że najskuteczniejszą metodą przeciwdziałania blokowaniu realizacji instalacji i urządzeń do przetwarzania odpadów są zachęty ekonomiczne. W realiach amerykańskich zgoda na tego typu inwestycje wiąże się z odczuwalnym obniżeniem kosztów związanych z odbiorem odpadów. Ponadto, jeśli przetwarzanie odpadów skutkuje produkcją energii, to sąsiedzi takiej instalacji mogą liczyć na znaczące bonifikaty w opłatach za jej dostawy [Wielgosiński, Namiecińska 2016].

W polskich realiach, dla terenów sąsiadujących z obiektami do przetwarzania odpadów, można pomyśleć przede wszystkim o obniżeniu podatków: od nieruchomości, rolnego i leśnego, a nawet o zaniechaniu ich pobierania, a także o obniżeniu lub całkowitym zwolnieniu z opłat za odbieranie odpadów oraz zwiększeniu częstotliwości odbioru.

$\mathrm{W}$ artykule pt. Zmiany w systemie gospodarki odpadami komunalnymi-aspekty prawne $i$ ekonomiczne na przykładzie m.st. Warszawy zasugerowano całkowita zmianę systemu opłat za gospodarowanie odpadami. Zaproponowano wprowadzenie jednej opłaty od każdego człowieka deklarującego miejsce zamieszkania na terenie Polski oraz ulgi i zwolnienia, np. dla seniorów [Wieczorek, Siekierski 2020] Wydaje się, że ten system można rozszerzyć o ulgi dla sąsiadów obiektów do przetwarzania odpadów.

\section{Materiały źródłowe}

\section{Literatura}

Gazeta.pl - forum regionalne wątek: Polfa Tarchomin - smród, https: / forum.gazeta.pl / forum/w,297,49723200,49723200,Polfa_Tarchomin_smrod.html [dostęp 19.01.2021].

Mikołajczyk M., 2020, Dzięki nam niebo jest niebieskie, Puls Biznesu - wydanie internetowe z 20.12.2020 r. https: / / www.pb.pl/ dzieki-nam-niebo-jest-niebieskie-1103783 [dostęp 19.01.2021].

Nowicki M., 1993, Strategia ekorozwoju Polski, Agencja Reklamowo-Wydawnicza A. Grzegorczyk, Warszawa.

Wieczorek A., Siekierski M., 2020, Zmiany w systemie gospodarki odpadami komunalnymi-aspekty prawne i ekonomiczne na przykładzie m.st. Warszawy, MAZOWSZE Studia Regionalne, 34, Mazowieckie Biuro Planowania Regionalnego, Warszawa, s. 31-58.

Wielgosiński G., Namiecińska O., 2016, Spalarnie odpadów komunalnych - perspektywa roku 2020, Nowa Energia, 2, Warszawa, s. 11-20. 


\section{Ustawy}

Ustawa z dnia 7 lipca 1994 r. Prawo budowlane (tj. z dnia 7 lipca 2020 r. Dz.U. z 2020 r. poz. 1333 z późn. zm.), w skrócie uPb.

Ustawa z dnia 21 sierpnia 1997 r. o gospodarce nieruchomościami (tj. z dnia 21 października 2020 r., Dz.U. z 2020 r. poz. 1990 z późn. zm.), w skrócie ugn.

Ustawa z dnia 27 marca 2003 r. o planowaniu i zagospodarowaniu przestrzennym (tj. z dnia 31 marca 2021 r. Dz.U. z 2021 r. poz. 741 z późn. zm.), w skrócie upzp.

Ustawa z dnia 20 stycznia 2005 r. o recyklingu pojazdów wycofanych z eksploatacji (tj. z dnia 27 października 2020 r. Dz.U. z 2020 r. poz. 2056).

Ustawia z dnia 10 lipca 2008 r. o odpadach wydobywczych (tj. z dnia 8 października 2020 r. Dz.U. z 2020 r. poz. 2018 z późn. zm.).

Ustawa z dnia 3 października 2008 r. o udostępnianiu informacji o środowisku i jego ochronie, udziale społeczeństwa w ochronie środowiska oraz o ocenach oddziaływania na środowisko (tj. z dnia 20 stycznia 2021 r. Dz.U. z 2021 r. poz. 247 z późn. zm.) w skrócie uiś.

Ustawa z dnia 24 kwietnia 2009 r. o bateriach i akumulatorach (tj. z dnia 16 września 2020 r. Dz.U. z 2020 r. poz. 1850).

Ustawa z dnia 14 grudnia 2012 r. o odpadach (tj. z dnia 15 kwietnia 2021 r., Dz.U. z 2021 r. poz. 779 z późn. zm.) w skrócie uod.

Ustawa z dnia 11 września 2015 r. o zużytym sprzęcie elektrycznym i elektronicznym (tj. z dnia 16 września 2020 r. Dz.U. z 2020 r. poz. 1893).

\section{Rozporządzenia}

Rozporządzenie Ministra Środowiska z dnia 29 grudnia 2016 r. w sprawie szczegółowego sposobu selektywnego zbierania wybranych frakcji odpadów (tj. z dnia 7 października 2019 r. Dz.U. z 2019 r. poz. 2028).

Rozporządzenie Rady Ministrów z dnia 10 września 2019 r. w sprawie przedsięwzięć mogących znacząco oddziaływać na środowisko (Dz.U. z 2019 r. poz. 1839), w skrócie rpzoś.

Rozporządzenie z dnia 2 stycznia 2020 r. Ministra Klimatu w sprawie katalogu odpadów (Dz.U. z 2020 r. poz. 10). 


\section{Uchwały}

Uchwała nr 88 Rady Ministrów z dnia 1 lipca 2016 r. w sprawie Krajowego planu gospodarki odpadami 2022.

Uchwała nr 3/19 Sejmiku Województwa Mazowieckiego z dnia 22 stycznia 2019 r. w sprawie uchwalenia Planu gospodarki odpadami dla województwa mazowieckiego 2024.

\section{Waste Management Waste processing installations and facilities}

\section{ABSTRACT}

Waste management is a complex process that can be briefly characterized as waste generation and waste management. Waste processing is absolutely crucial to waste management. For waste processing - recovery and disposal - suitable installations and facilities are required, the overwhelming majority of which are public purpose investments (as defined in the Act on Spatial Planning and Development) and projects that may always have a significant impact on the environment (as defined in the Regulation on projects likely to have a significant impact on the environment). The installations and facilities mentioned above are treated as construction objects within the meaning of the Construction Law or are situated in such objects.

This is the second in a series of articles on waste management. It discusses the principles of building construction objects in which waste processing takes place (and the problems related thereto). The authors believe that the main causes of the problems are too complex procedures for determining the location and obtaining a building permit and negative social attitudes - people do not want to have such facilities in their neighbourhood.

The article does not include detailed considerations on: the simplification of procedures for determining the location of the above-mentioned buildings, environmentally friendly technologies, the number of installations necessary for proper waste management in Poland, economic incentives. These topics are too extensive for a single article. They require a series of separate studies and publications.

The authors only indicate: which acts of law should be first changed in order to simplify procedures, ways to cool down negative emotions: economic incentives for property owners, located in the broadly understood neighbourhood of the above-mentioned facilities.

Key words: projects that may always have a significant impact on the environment, waste, waste management, waste disposal, waste processing, thermal treatment of waste 


\title{
44 GOSPODARKA ODPADAMI. INSTALACJE I URZĄDZENIA DO PRZETWARZANIA ODPADÓW
}

Anna Wieczorek, Maciej Siekierski

\begin{abstract}
Anna Wieczorek - na Politechnice Warszawskiej ukończyła Wydział Architektury, Podyplomowe Studium Urbanistyki, Studium Doskonalenia Pedagogicznego oraz uzyskała dyplom doktora nauk technicznych. Posiada uprawnienia do projektowania w planowaniu przestrzennym oraz uprawnienia do pełnienia samodzielnych funkcji technicznych w budownictwie. Specjalizuje się w wykonywaniu projektów miejscowych planów zagospodarowania przestrzennego (główny projektant ponad 30 uchwalonych projektów planów miejscowych) oraz projektów studiów uwarunkowań i kierunków zagospodarowania przestrzennego gmin (główny projektant 5 uchwalonych stdiów). Ma doświadczenie w pracy ze studentami - na Politechnice Warszawskiej i w Wyższej Szkole Przedsiębiorczości i Administracji w Lublinie. Należy do Mazowieckiej Okręgowej Izby Architektów z siedzibq̨ w Warszawie oraz Pan-Europejskiej Federacji Ochrony Zabytków - Europa Nostra z siedzibq w Holandii.

Anna Wieczorek - graduate of the Warsaw University of Technology - Faculty of Architecture, Postgraduate Town Planning Studies, Pedagogical study, PhD in technical science. Holds professional permits for spatial planning and is authorised to perform independent technical functions in construction. Specialises in the preparation of local spatial development plans (is the main designer of more than 30 approved local development plans) and of the studies of conditions and directions of the spatial development of municipalities (main designer of 5 approved studies). Has experience in working with students - at the Warsaw University of Technology and the University College of Enterprise and Administration in Lublin. Member of the Warsaw-based Masovian Chamber of Architects and the Pan-European Federation for Cultural Heritage, Europa Nostra based in the Netherlands.
\end{abstract}

Maciej Siekierski - dr hab. inż. adiunkt w Katedrze Chemii Nieorganicznej Wydziału Chemicznego, autor i współautor prawie 200 publikacji naukowych cytowanych około 500 razy (623 z pominięciem autocytowań 460), (indeks Hirsha równy 9 wg Scribus, 12 według SCOPUS). Ponadto w dorobku istotna część stanowi współautorstwo w ponad 100 wystąpieniach konferencyjnych. Około połowy z nich było prezentowane osobiście. Kierownik, główny wykonawca i wykonawca wielu projektów badawczych i dydaktycznych finansowanych przez NCBiR, NCN, KBN, UE, EOG i NATO. Kierownik i wykonawca badań przemysłowych prowadzonych na zlecenie wiodących firm z sektora energetycznego (PSE Operator, ENEA, PGE, PKP PLK). Laureat nagród (Rektora PW i Prezesa Rady Ministrów). Wizytował szereg ośrodków naukowych (Kanada, Niemcy, Francja, Hiszpania). Od początku 2019 reprezentuje Wydział Chemiczny Politechniki Warszawskiej w Radzie Klastra Gospodarki Odpadowej i Recyklingu. Od czerwca 2019 roku pełni funkcję przewodniczqcego Rady Ekspertów KGOiR.

Maciej Siekierski - PhD Eng, DSc, Assistant Professor at the Department of Organic Chemistry in the Faculty of Chemistry, author and co-author of almost 200 scientific publications cited about 500 times (623; 460 excluding self-citations), (Hirsch index equal of 9 according to Scribus, 12 according to SCOPUS). Moreover, a significant part of his achievements is the co-authorship of over 100 conference speeches. About half of them were presented in person. Supervisor, main contractor and contractor of many research and didactic projects financed by NCRD, NSC, KBN, EU, EEA and NATO. Supervisor and contractor of industrial research conducted at the request of leading companies in the energy sector (PSE Operator, ENEA, PGE, PKP PLK). Laureate of the Rector of WUT's award and the Prime Minister's award. Visited several research centres (Canada, Germany, France, Spain). Since the beginning of 2019, has been representing the Faculty of Chemistry at the Warsaw University of Technology in the Council of the Waste Management and Recycling Cluster. Since June 2019, holds the position of the Chairman of the Council of Experts in the WMRC. 